\title{
The puzzle of the circular features in Inglefield Land, North-West Greenland
}

In 1994 The Geological Survey of Greenland (GGU) conducted an airborne geophysical survey of Inglefield Land, North-West Greenland, financed by the Government of Greenland, Minerals Office. During photogeological studies in connection with the survey well over 100 circular structures were identified in a belt stretching from the Inland Ice across central Inglefield Land to the coast (Fig. 1; Bengaard, 1995). The structures were also identified on videorecordings from the airborne geophysical programme. The circular structures are up to $80 \mathrm{~m}$ across, and conspicuous due to their generally dark colour which contrasts with surrounding areas (Fig. 2). Some are ring-shaped, with the dark material concentrated around the circumference of the circles, while others are dark-coloured across their entire area.

Prior to GGU's investigations, the circular structures on Inglefield Land had been identified during a reconnaissance photogeological interpretation (Sharp, 1991), but had not been checked on the ground. The more detailed information available on the video-recordings from 1994 triggered numerous discussions concerning the origin of the structures and a variety of explanations were speculated on. The structures were interpreted to represent volcanic pipes (Stemp \& Thorning, 1995), and thus particularly inter- esting if they were kimberlite pipes. Other suggestions discussed in house at the time were meteoritic impacts or permafrost features such as pingos. The idea that the structures represented kimberlite pipes caused several mining companies to apply for concessions in Inglefield Land. One company which had obtained a concession in the area carried out field work during June 1995, with the author as a participant. In July and August the Geological Survey of Denmark and Greenland (GEUS) carried out field work in the area, again with the author as a participant. During this field work a glacial origin of the circular structures was proved most likely (Appel, 1996)

Central Inglefield Land is a peneplain consisting of Precambrian gneisses and supracrustal rocks intruded by granites and syenites, and overlain by upper Proterozoic and Cambrian sediments. The surface of the peneplain is dominated by large boulder fields with scattered outcrops. The circular structures, named Minturn circles after the river Minturn Elv (Appel, 1996), occur in a fan-shaped belt about $40 \mathrm{~km}$ long and up to $25 \mathrm{~km}$ wide (Fig. 1), and are most abundant in the southern part of the belt. More than 300 circles and rings have been observed, of which about 175 have been investigated on the ground.

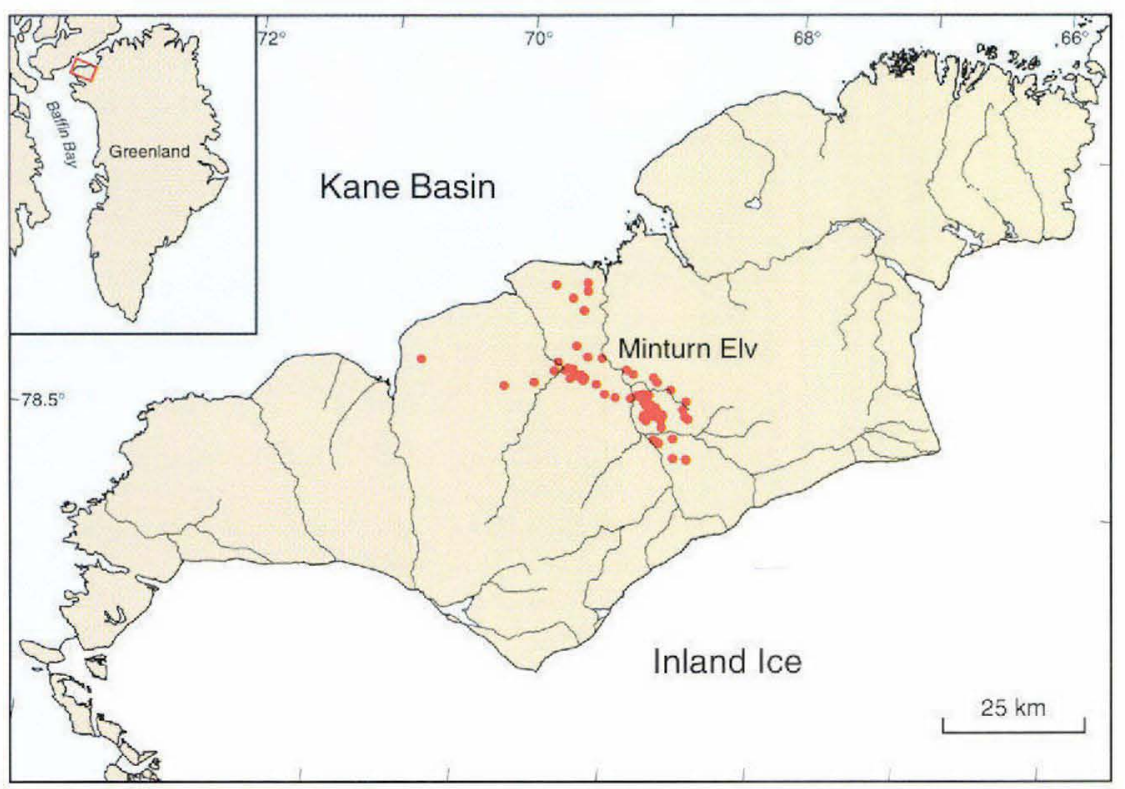

Fig. 1. Fan-shaped area with circular structures across central Inglefield Land. Only circular structures close to the border of the fanshaped area are indicated. Thus in the central part, numerous circles and rings occur which are not shown on the map. 


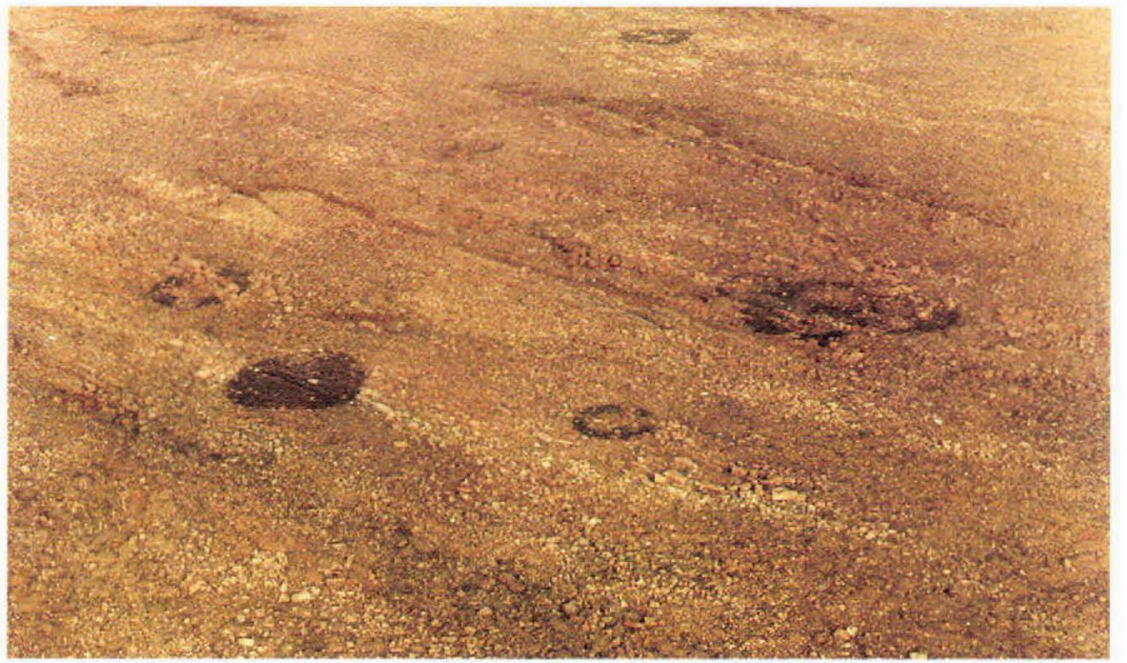

Fig. 2. Minturn circles including ring-shaped examples on boulder field of Precambrian gneisses in central Inglefield Land. Many of them have been disturbed by frostboils. The largest circle is about $50 \mathrm{~m}$ across. Aerial photograph.

The Minturn circles range in size from a few metres to about $80 \mathrm{~m}$. The width of the rings in the ring-shaped type varies from a few metres to about $8 \mathrm{~m}$. The dark rings and circles consist of angular to slightly rounded boulders, cobbles and pebbles of syenite mostly covered by black lichens, which contrast strongly with the light coloured Precambrian gneisses and Cambrian sediments (Fig. 2).

The circular structures are at the same level as the surrounding boulder fields and outcrops. The syenite boulders occur as thin sheets, often just one layer thick, which as carpets drape the boulder fields and outcrops of Precambrian gneisses and Proterozoic to Cambrian sediments on which they occur. These carpets are not only found on flat surfaces but also on slopes.

The field relationships clearly show that the Minturn circles are not volcanic pipes, nor are they permafrost features. They cannot have been deposited by running water, and it is therefore concluded that they were deposited from an extension of the Inland Ice.

The first stage in the formation of the circular structures is thought to take place within so-called cold ice (which means the the ice margin is frozen to the ground due to permafrost) by a melting/refreezing process similar to that described by Boulton $(1970,1972)$ and Weertman (1971). In Inglefield Land this process took place over a large syenite complex in south central Inglefield Land where ice wedges with syenite debris were formed and subsequently transported towards the north. During melting of the ice cover, the debris became exposed on the surface of the ice sheet and subsequently concentrated in evolving meanders of stream systems developed on the flat, stagnant Inland Ice. When the ice finally melted the ring-shaped and circular accumulations were gently deposited on the flat plains of Inglefield Land.

Circular deposits as found in central Inglefield Land are probably quite common in the high arctic. They are, how- ever, mostly invisible, as the surrounding rock types tend to have the same compositions as the circular deposits.

In the 1950 s comparable circular structures were spotted from the air in North-East Greenland. Follow-up field work on the ground was not possible at that time, and they were provisionally interpreted as impact structures (Ellitsgaard-Rasmussen, 1954). Observations on the ground by GGU geologists H. F. Jepsen and F. Kalsbeek in 1979, and in 1995 by T. Tukiainen and M. Lind showed these circles to consist of dark basalt blocks deposited on light coloured sediments, closely resembling in appearance and probably also in origin the Minturn circles of Inglefield Land.

\section{References}

Appel, P. W. U. 1996: A new type of glacial deposit. Nature 379 , 590-591.

Bengaard, H,-J. 1995: Photogeological interpretation of Inglefield Land, North-West Greenland. Open File Ser. Grosnlands geol. Unders. 95/4, $21 \mathrm{pp}$.

Boulton, G. S. 1970. On the origin and transport of englacial debris in Svalbard glaciers. J. Glaciol. 9, 213-229.

Boulton, G. S. 1972. Modern Arctic glaciers and depositional models for former ice sheets. J. Geol. Soc., London 128, 361393.

Ellitsgaard-Rasmussen, K. 1954: Meteoric shower in North-East Greenland? Meddr Dansk geol. Foren. 12, 433-435.

Sharp, G. 1991: Gossan search on Inglefield Land, North West Greenland. R. T. Z. Mining and Exploration Limited, unpublished report, $14 \mathrm{pp}$.

Stemp., R. W. \& Thorning, L. 1995: Airborne electromagnetic and magnetic survey of Inglefield Land, North-West Greenland. Results from project AEM Greenland 1994. Open File Ser. Gronlands geol. Unders. 95/1, 45 pp.

Weertman, J. 1971. Mechanism for the formation of inner moraines found near the edge of cold ice caps and ice sheets. J. Glaciol. 3, 965-978.

P. W. U. A., Geological Survey of Denmark and Greenland, Copenhagen 